\title{
Beta-lactamase resistance genes in Enterobacteriaceae from Nigeria
}

Babafela Awosile ${ }^{1 *}$, Michael Agbaje ${ }^{2}$, Oluwawemimo Adebowale ${ }^{2}$, Olugbenga Kehinde ${ }^{2}$, Ezekiel Omoshaba ${ }^{2}$

${ }^{1}$ Department of Health Information and Performance, Health PEI, Charlottetown Canada

${ }^{2}$ College of Veterinary Medicine, Federal University of Agriculture, Abeokuta Nigeria

*Dr. Babafela B. Awosile

Department of Health management, Atlantic Veterinary College, University of Prince Edward Island, C1A 4P3 Charlottetown,

Canada.

bawosile@upei.ca 


\begin{abstract}
This review was carried out to identify different beta-lactamase resistance genes reported in published literature from Nigeria and to determine the proportion estimates of the important beta-lactamase resistance genes in Nigeria. Sixty-three (63) articles were included in this review based on the eligibility criteria. All the beta-lactamases reported were detected from the Gramnegative bacteria, most especially from Enterobacteriaceae $(\mathrm{n}=53)$. Thirty-six different betalactamase genes have been reported from Nigeria. These genes belong to the narrow-spectrum, AmpC, extended-spectrum, and carbapenemase beta-lactamase resistance genes. Eight (8) genes (bla $a_{\mathrm{DHA}}, b l a_{\mathrm{CTXM}-1}, b l a_{\mathrm{CTXM}-14}, b l a_{\mathrm{GES}-1}, b l a_{\mathrm{VEB}-1}, b l a_{\mathrm{OXA}-1}, b l a_{\mathrm{OXA}-2,}$ and $\left.b l a_{\mathrm{TEM}-1}\right)$ were shared between animals and humans, 5 genes $\left(\right.$ bla $_{\mathrm{SHV}-1}$, bla $_{\mathrm{SHV}-2}, b_{\mathrm{SHV}-11}, b_{\mathrm{SHV}-12}$, and bla $\left._{\mathrm{NDM}-1}\right)$ were common to both humans and environment while none of the genes was unique to both animals and environment. Four genes including $b l a_{\mathrm{CMY}}, b l a_{\mathrm{TEM}-1}, b l a_{\mathrm{AmpC}}$, and internationally pandemic

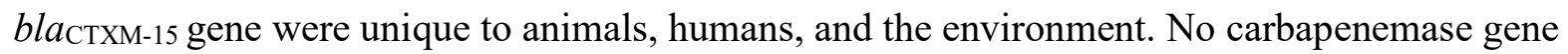
was reported from animals yet. The pooled proportion estimate of ESBL genes in Nigeria was

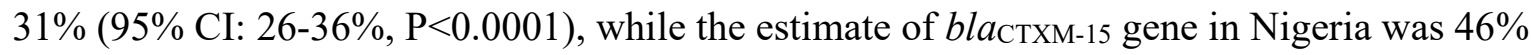
(95\% CI: 36-57\%, $\mathrm{P}<0.0001$ ). The proportion estimate of AmpC genes was 32\% (95\% CI: $11-$ $52 \%, \mathrm{P}<0.001)$, while the estimate for carbapenemases was $8 \%$ (95\% CI: $5-12 \%, \mathrm{P}<0.001)$. This study has provided information on the beta-lactamases distribution in Nigeria. This is necessary for a better understanding of molecular epidemiology of clinically important beta-lactamases especially the extended-spectrum beta-lactamases and carbapenemases in Nigeria.
\end{abstract}

Keywords: Antimicrobial resistance, Beta-lactamase gene, Nigeria, Review 
Introduction

Beta-lactam antimicrobials are one of the most important groups of antimicrobial drugs in both human and animal health. Antimicrobials such as extended-spectrum cephalosporins (ESC) and carbapenems have been categorized by the WorldHealth Organization as a last resort and critically important antimicrobials, with limited alternatives in the cases of resistance development ${ }^{1}$. However, antimicrobial resistance (AMR) to this group of antimicrobials is occurring at a rapid rate on a global scale ${ }^{2}$. Most resistance to beta-lactams in Enterobacteriaceae is mainly due to the production of beta-lactamases, which are often encoded either chromosomally or on plasmids ${ }^{3,4}$.Production of beta-lactamases such as extendedspectrum beta-lactamases (ESBLs), AmpC beta-lactamases and carbapenemase beta-lactamases have increasingly been detected worldwide to be distributed in food animals, companion animals, wildlife, humans, and environments ${ }^{4,5}$. Also, since AMR is a One Health challenge, several beta-lactamase genes have been disseminated across different resistant bacterial populations from different hosts and environments ${ }^{6}$.

Beta-lactamase production in Enterobacteriaceae is an emerging public health concern due to therapeutic failure, serious consequences for infection control and increased risk of morbidity and mortality in both animal and human health ${ }^{7}$.The predominant ESBL genes encountered are $b l a_{\mathrm{CTXM}}, b l a_{\mathrm{TEM}}$, and $b l a_{\mathrm{SHV}}$. The prevalent AmpC beta-lactamase is bla $a_{\mathrm{CMY}-2 \text {, }}$ while for carbapenemases; bla $a_{\mathrm{NDM}-1}$ and bla $\mathrm{OXX}_{-48}$ have been commonly reported globally ${ }^{5}$. Although several numbers of beta-lactamase genes have been reported worldwide, not all are equally prevalent among human and animal bacteria. Also, the occurrence, as well as the prevalence of these resistance genes, varies across different geographic regions. For instance,

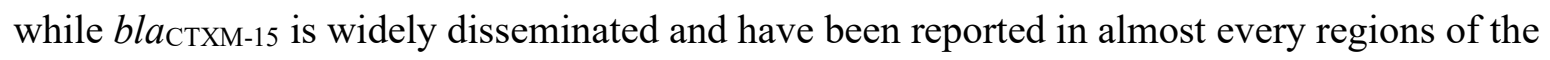


world, AmpC bla $\mathrm{CMY}-2_{2}$ have been mostly encountered in North America in both animal and human settings ${ }^{8}$.

Therefore, there is a need for continuous surveillance of beta-lactamase resistance genes for a better understanding of the epidemiology of these genes locally within a country and to determine the extent of global dissemination. While detailed information on AMR at the national level do exist for the developed countries such as USA, Canada, and other European countries through integrative surveillance, this is often lacking in most developing countries in Africa including Nigeria. Therefore, generation of AMR data through the use of systematic review of published researches is a useful tool that can give a glimpse of state and extent of AMR in developing countries such as Nigeria. In this study, a systematic review was carried out to identify different beta-lactamase resistance genes reported in published literature from Nigeria, to describe the distribution of these genes between animal, human and environmental settings, and to determine the proportion estimates of the different beta-lactamase resistance genes in Nigeria. This systematic review was conducted based on the Preferred Reporting Items for Systematic Reviews and Meta-Analyses (PRISMA) checklist ${ }^{9}$.

\section{Methods}

\section{Literature search and data sources}

The literature search was conducted in PubMed, Google scholars and African Journal Online (AJOL) electronic databases using a combination of Boolean operators (AND/OR) and predefined keywords. We used the following terms for our search: beta-lactamases AND Nigeria OR beta-lactamase resistance genes AND Nigeria, bla Стхм AND Nigeria, bla $a_{\mathrm{TEM}}$ AND Nigeria, bla $\mathrm{SHv}_{\mathrm{H}}$ AND Nigeria, bla $\mathrm{OxA}_{\mathrm{X}}$ AND Nigeria, Carbapenemases AND Nigeria, AmpC betalactamase resistance AND Nigeria, extended-spectrum beta-lactamase resistance AND Nigeria. 
The reference lists of all eligible articles were further reviewed and used to carry out a supplementary literature search. The articles were further screened after removal of duplicates based on titles and abstracts for their relevance to the study objectives and purpose. Articles included in this review were limited to the available publications up till December 2019.

\section{Study selection and eligibility}

The primary outcome of interest was the distributions and different types of betalactamase resistance genes from bacteria from all sources in Nigeria across one health interface. All studies reporting beta-lactamase resistance genes were included in the review. However, for any study to be included in this qualitative review, the studies must have performed molecular detection of beta-lactamase resistance genes. Studies that only reported beta-lactamase production based on phenotypic synergy test without beta-lactamase gene detection were excluded from the review. Studies with extractable data on the proportions of different types of beta-lactamase resistance genes from animals, humans and the environment were further considered.

\section{Data extraction and analysis}

The data were abstracted onto Excel (Microsoft Office Excel 2010) spreadsheet. For each eligible study, data extracted included: first author details, year of publication, type of sample collected (animal feces, retail meat products, human clinical samples, environmental samples), sources of the samples (animal, human or environment), bacterial species isolated, study location or geopolitical zone of the study in Nigeria, sample size of bacterial isolated, different types of beta-lactamase resistance genes detected, number of bacterial isolates positive for the betalactamase genes phenotypically, number of bacterial isolates positive for the beta-lactamase genes genotypically, antimicrobial susceptibility testing method (disk diffusion, micro-broth 
dilution, agar dilution, E-test, or automated methods), phenotypic and genotypic methods of beta-lactamase detection. The proportion (with respective $95 \%$ confidence interval) of each betalactamase gene as reported for each study was calculated by dividing the number of bacteria positive for the beta-lactamase gene by the total number of bacteria positive phenotypically or total number of bacteria isolated depending on the data availability.

Random-effects meta-analysis was used to calculate the pooled (weighted) proportions with respective $95 \%$ confidence intervals for the different types of the beta-lactamase groups. The analysis was done to allow for any heterogeneity between studies. Studies reporting a low number of bacterial isolates $(<10$ isolates) were not included in the meta-analysis. The pooled prevalence and each study estimates were presented using forest plot. The $I^{2}$ statistic (a measure of inconsistency) was used to assess the variation between studies due to heterogeneity. A value of $0 \%$ shows no observed heterogeneity; increasing values indicate increasing heterogeneity. The $I^{2}$ statistic with cutoff values $\leq 25 \%, \geq 26-\leq 50 \%$, and $>5 \%$ were subjectively considered as low, moderate, and substantial heterogeneity. Subgroup analysis was performed to account for potential sources of heterogeneity between studies. A separate meta-analysis was carried out for each of the dominant beta-lactamase group. Statistical significance was set at $\mathrm{P}<0.05$ while statistical analysis was carried out using STATA SE/15.0 (College Station, Texas 77845 USA).

\section{Result}

\section{Study characteristics}

Systematic search from two electronic databases identified 567 articles (197 from PubMed, 30 from AJOL and 340 from Google scholar). The outline of study selection and review process is shown in the PRISMA flowchart (Figure.1). Sixty-three articles (63) were included in the subsequent qualitative review following the assessment of the 128 published 
articles for eligibility. A qualitative review of the 63 studies on beta-lactamase resistance genes in Nigeria was based on studies in animals $(n=13)$, humans $(n=41)$ and environment $(n=9)$. Studies of animal origin were from poultry, pig, cattle, pigeons, and duck. However, all the human studies were hospital-based, with the beta-lactamases reported from clinical samples collected within the hospitals in Nigeria. While for environment-based studies, samples were collected from wastewater, drinking water, beach water, aquatic, and river samples.

Among the 63 studies reviewed, detection of beta-lactamases were all from Gramnegative bacteria most especially from bacterial family Enterobacteriaceae $(\mathrm{n}=60)$, while others include Acinetobacter baumannii $(\mathrm{n}=2)$ and Vibrio spp. $(\mathrm{n}=1)$. Majority of the studies were carried out in the Southwestern Nigeria $(n=39)$, while other regions include South-eastern $(n=8)$, North-central $(n=5)$, North-eastern $(n=3)$, North-western $(n=2)$ and South-southern $(n=2)$ Nigeria. Seventeen $(n=17)$ studies used broth microdilution method to determine the minimum inhibitory concentrations (MIC) for various antimicrobials tested, other methods used for MIC determination include E-test $(n=4)$, and Vitek-2 $(n=3)$. However, disc diffusion method $(n=36)$ was mainly use for the determination of susceptibility of bacteria to various antimicrobials tested. Only 46 of the 63 studies reported the use of phenotypic screening method for betalactamase production; this includes modified Hodge test and Carba test $(\mathrm{n}=6)$ for carbapenemases production as well as double disk synergy test $(n=39)$ for other beta-lactamase production. Forty-eight studies used polymerase chain reactions (PCR) alone ( $n=48)$, PCR with sequencing ( $n=9)$, PCR with isoelectric point $(n=2)$, PCR with whole genome sequencing $(n=1)$, PCR with restriction fragment length polymorphism (RFLP, $n=1$ ) and whole genome sequencing alone $(n=2)$ for the genotypic detections of various beta-lactamase resistance genes reported in the reviewed studies. 
One health distribution of beta-lactamase resistance genes in Nigeria

Thirty-six (36) different beta-lactamase genes were detected and reported in the 63 studies (Table 1). Seventeen (17) genes were detected from animals, 28 genes from humans and 12 genes from the environment. These genes belongs to the $\mathrm{AmpC}{ }^{10-24}$, extended-spectrum ${ }^{10-}$ 15,17,19,20,23-56 , narrow-spectrum ${ }^{13-16,19,24,32,35,37,43,57-59}$, and carbapenemase beta-lactamase resistance genes ${ }^{19,22,59-66}$. One health distribution of beta-lactamase resistance genes between the animal, human and environmental settings was presented in Table 1. Eight (8) genes (bla $a_{\mathrm{DHA}}$, bla $_{\mathrm{CTXM}-1}$, bla $_{\mathrm{CTXM}-14}, b_{\mathrm{GES}-1}, b_{\mathrm{VEB}-1}, b l_{\mathrm{OXA}-1}, b a_{\mathrm{OXA}-2,}$ and $\left.b a_{\mathrm{TEM}-1}\right)$ were shared between animals and humans, 5 genes (bla SHV-1, $_{\text {bla }} a_{\mathrm{SHV}-2}$, bla $_{\mathrm{SHV}-11}$, bla $_{\mathrm{SHV}-12}$, and bla $\left._{\mathrm{NDM}-1}\right)$ were common to both humans and environment while none of the genes was unique to both animals and environment. Four genes including $b l a_{\mathrm{CMY}}, b l a_{\mathrm{TEM}-1}, b l a_{\mathrm{AmpC}}$, and internationally pandemic bla $a_{\mathrm{CTXM-15}}$ gene were unique to animals, humans, and the environment. No carbapenemase gene was reported from animals yet. While 7 genes $\left(\right.$ bla $_{\mathrm{CMY}-2}, b l a_{\mathrm{ACT}-5}, b l a_{\mathrm{ACC}}, b l a_{\mathrm{FOX}-1}, b l a_{\mathrm{ECB}}$,

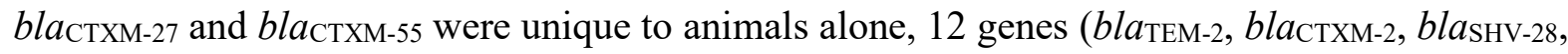
bla $_{\mathrm{SHV}=112}$, bla $_{\mathrm{OXA}-10}$, bla $_{\mathrm{OXA}-23}$, bla $_{\mathrm{OXA}-48}$, bla $_{\mathrm{OXA}-181}, b_{\mathrm{NDM}-5}, b_{\mathrm{VIM}-1}, b_{\mathrm{VIM}-2}$ and bla $\left._{\mathrm{KPC}}\right)$ were unique to humans alone; however, only 2 genes ( $b l a_{\mathrm{VIM}-5}$ and $\left.b l a_{\mathrm{Z}}\right)$ were unique to the environment.

\section{Proportion estimates of extended-spectrum beta-lactamase genes in Nigeria}

Thirty-two studies were included in the meta-analysis for the generation of overall pooled estimate of ESBL. The overall pooled proportion of ESBL was 31\% (95\% CI: $26-36 \%$, $\mathrm{P}<0.001)$. The overall between-study heterogeneity was significant and substantial $\left(I^{2}=97.87 \%\right.$, $\mathrm{p}<0.001$ ). Between the studies, the proportions of ESBL genes ranges from 1-95\% (Figure 2). 
Subgroup analysis provide some explanation for the between-study heterogeneity and also pooled proportion of ESBL based on one health distribution Subgroup analysis revealed the between study heterogeneity was due to human and animal studies. The overall proportion estimate of ESBL for human was 35\% (95\% CI: $27-43 \%, \mathrm{P}<0.001)$, while the estimate for animal was $25 \%(95 \%$ CI: $17-33 \%, \mathrm{P}<0.001)$ and $22 \%(95 \% \mathrm{CI}: 0-44 \%, \mathrm{P}=0.06)$ for the environmental-based studies. A separate meta-analysis was conducted to determine the

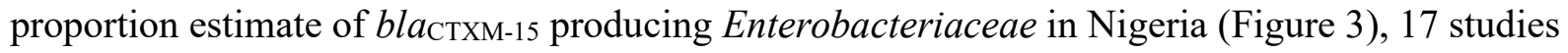
were included in the quantitative analysis. The overall pooled proportion was $46 \%$ (95\% CI: $36-$ $57 \%)$, the unexplained between-study heterogeneity was significant and substantial $\left(I^{2}=99.04 \%\right.$, $\mathrm{p}<0.001)$. The proportion estimate of bla $a_{\mathrm{CTXM}-15}$ gene from human-based studies was $47 \%$ (95\% CI: $25-69 \%$ ), for the animal-based studies, the pooled proportion was $47 \%$ (95\% CI: $27-$ $67 \%)$ and that of the environment was $41 \%$ (95\% CI: 33-50\%). Between subgroups, heterogeneity was non-significant $(\mathrm{P}=0.812)$. However, the within-group heterogeneity for both human and animal studies was significant and substantial $\left(I^{2}=99 \%, \mathrm{P}<0.001\right)$.

\section{Proportion estimates of AmpC and carbapenemase beta-lactamase genes in Nigeria}

Based on 13 studies, the overall pooled proportion of AmpC beta-lactamases was $32 \%$ (95\% CI: $11-52 \%, \mathrm{P}<0.001)$, with the overall between-study heterogeneity was significant and substantial $\left(I^{2} 99.15 \%, \mathrm{p}<0.001\right)$. However, the proportions of AmpC beta-lactamases reported from the studies ranges from 2-88\% (Figure 4). Subgroup analysis revealed that between-study heterogeneity was due to studies from human settings. The proportion of AmpC beta-lactamases was higher in human 37\% (95\% CI: 4-70\%, P=0.03) than environment $20 \%$ (95\% CI: $14-25 \%$, $\mathrm{P}<0.001)$ and animals $26 \%$ (95\% CI: 0-64\%, $\mathrm{P}=0.20)$. 
Six studies were included in the carbapenemases pooled proportion estimation (Figure 5). The overall pooled proportion of carbapenemases was $8 \%$ (95\% CI: $5-12 \%, \mathrm{P}<0.001)$. Between the studies, the proportions of carbapenemase beta-lactamases ranges from $1-48 \%$, while the overall between-study heterogeneity was significant $\left(I^{2}=87.6 \%, \mathrm{p}<0.001\right)$. Subgroup analysis provide some explanation for the between-study heterogeneity and also pooled proportion of carbapenemases based on one health distribution (Figure 4). The proportion of carbapenemases for environment was $15 \%(95 \%$ CI: $8-22 \%, \mathrm{P}<0.001)$ and was higher than $6 \%$ of human $(95 \%$ CI: 3-10\%, $\mathrm{P}<0.001)$. Between study heterogeneity was mostly due to studies from human setting.

\section{Discussion}

In Africa, data on AMR are often limited due to lack of sustainable integrated surveillance programs at country level. Lack of systematically collected data has contributed largely to the poor understanding of AMR to critically important antimicrobials such as betalactam drugs in Africa compared to the developed world. This study was conducted to bridge some of these gaps by identifying different types, distribution and the proportion estimates of beta-lactamase resistance genes reported in published literature in Nigeria. This is for the purpose of generating data and information for the national, continental, and global understanding of molecular epidemiology of beta-lactamases. While this review was based on published articles in Nigeria, it is a step in right direction to provide data that can support the establishment of necessary preventative measures such as integrative surveillance programs and policies for the mitigation of AMR within Nigeria. From this review, beta-lactamases were mainly detected from bacteria of the family Enterobacteriaceae. This is unsurprising as the Gram-negative bacteria of the Enterobacteriaceae family are ubiquitous in nature, causing different infections (most especially $E$. coli) in both humans and animals and can readily be 
maintained in the environment. Also, the emergence and occurrences of AMR due to betalactamases in Enterobacteriaceae are driven mainly by MDR characteristics, ease of acquisition of AMR genes, and rapid dissemination of resistance determinants by Enterobacteriaceae to other pathogenic and non-pathogenic bacteria ${ }^{2,67}$.

Among the 63 studies, $73 \%$ reported double-disk synergy test for the phenotypic detection of beta-lactamases prior to the genotypic method. This is in compliance with CLSI guideline for the screening and detection of beta-lactamases in bacteria. However, five different genotypic methods including PCR, DNA sequencing, WGS, isoelectric point, and RFLP were reported by the studies. PCR method was mostly reported from published articles reviewed; this may be due to ease of access and reduced cost associated with PCR compared to other advanced techniques such as DNA sequencing and WGS ${ }^{68}$. While WGS method is commonly used in the developed world both in research and surveillance programs, the use of WGS in beta-lactamase studies in Nigeria is still limited. Only two studies reported the use of WGS for the detection of beta-lactamase genes. This may be due to the lack of accesses to necessary software, technicalknow-how, and bioinformatics intricacy as well as other computational difficulties associated with the use of WGS in a developing country as Nigeria.

Majority of the articles published were from southern Nigeria compared to northern Nigeria. Therefore, beta-lactamases reported in this systematic review may not reflect the true picture of the beta-lactamases distributed in Nigeria geographically. However, of all the betalactamases detected in Nigeria, the majority of the articles were from human clinical settings compared to the animal and environmental settings which is consistent with what has been reported from a similar study in South Africa ${ }^{68}$. In most cases, human clinical settings routinely carry out antimicrobial susceptibility testing and other AMR phenotypic tests before clinical 
treatment. Also, further genomic laboratory work may routinely be carried out to determine what epidemiological type of beta-lactamases is responsible for the beta-lactam resistance. Therefore, this may explain detection and report of beta-lactam resistance from human clinical settings compared to animal and environmental settings where detections are mostly not routine but research-based

From this review, 36 different types of beta-lactamases have been detected and reported in Nigeria, and these beta-lactamases included the clinically important types such as ESBL, $\mathrm{AmpC}$, and carbapenemases that are commonly responsible for treatment failures in both human and veterinary settings ${ }^{69,70}$.While previous reviews within Africa focused mainly on systematic reviews of ESBL in Enterobacteriaceae ${ }^{71-73}$, this study was conducted to capture as many betalactamases detected in Nigeria as possible beyond ESBL. This is because ESBLs, the AmpCtype, and the carbapenemases remain the most clinically challenging beta-lactamase resistance gene families in both human and animal health. Antibiotic resistance is recognized as a one health challenge because of the rapid emergence, molecular relatedness and dissemination of important resistant bacteria and genes among humans, animals, and the environment at a global scale $^{74}$. This review showed that of the 36 beta-lactamases reported in Nigeria, some of the genes detected in Nigeria were reported from more than one setting. Between human clinical setting and environment, 5 different beta-lactamases have been reported while between animal and human settings, 8 different genes have been reported. This finding further highlights the importance of one health transmission pathway of AMR between human, animal and environmental settings. Also, it revealed how environmental contamination and food-animal production systems could serve as reservoirs of essential AMR genes, transmission and 
colonization as well as infection with clinically important beta-lactamase producing bacteria in humans ${ }^{6}$.

Epidemiologically, all the beta-lactamases detected in Nigeria have been reported from other parts of the world. Five different types of AmpC beta-lactamase group (bla $a_{\mathrm{CMY}-2,}$, bla $_{\mathrm{ACT}}$, $b l a_{\mathrm{ACC}}, b l a_{\mathrm{FOX}-1}$, and $\left.b l a_{\mathrm{DHA}}\right)$ were reported in Nigeria to date based on this review. While bla $_{\mathrm{CMY}-2}$ is the most important AmpC type and with broadest geographic spread, this gene was not common in Nigeria based on this review compared to other countries such as United States of America and Canada where the gene is most common in livestock and retail meat products, as well as in non-typhoidal salmonella infections in humans ${ }^{8}$. Within Africa, there are limited reports on $\mathrm{AmpC}$ beta-lactamases. However, bla ${ }_{\mathrm{CMY}-2}$ and bla $_{\mathrm{DHA}}$ have been reported from Algeria ${ }^{71}$, while $b l a_{\mathrm{ACC}}, b l a_{\mathrm{FOX}-1}$, and bla $_{\mathrm{DHA}}$ from Uganda ${ }^{75}$.No carbapenemase was reported yet from animals in Nigeria based on this review, however, carbapenemases have been commonly reported from wildlife, food-producing animals, and companion animals from other countries ${ }^{70,76}$, the lack of report of carbapenemase from animal setting may be due to lack of research or surveillance in this regard and not necessarily absence of carbapenemase genes in animals from Nigeria. All the epidemiologically important carbapenemases including bla $\mathrm{OXA}-23$,

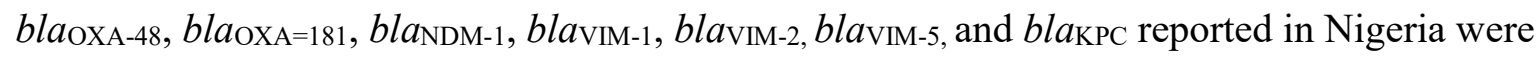
mostly from the human clinical setting. These carbapenemases have been described in many African countries including South Africa, Gabon, Angola, Senegal, Kenya, Tanzania, Morocco, Algeria, Tunisia, Libya, and Egypt ${ }^{77,78}$. In most cases, bla $_{\mathrm{NDM}-1}$ and bla OXA-48 $_{\text {in }}$ is the commonly reported carbapenemases. While these carbapenemases are known to be prevalent in the South Asian countries most especially from India sub-continent, the trend in Africa may indicate that 
global dissemination of carbapenemase-producing Enterobacteriaceae has reached the African continent.

Among the ESBLs, five different groups were reported including bla $a_{\mathrm{CTXM}}, b l a_{\mathrm{SHV}}$, bla $_{\mathrm{OXA}}, b a_{\mathrm{GES}}$ and $b l a_{\mathrm{VEB}}$, with bla $a_{\mathrm{CTXM}}$ most commonly reported. During the last decade,

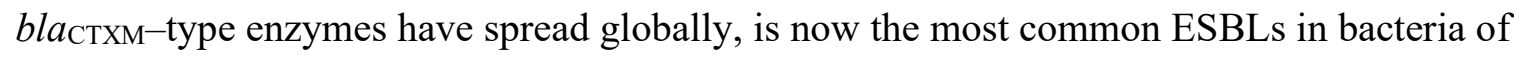
Enterobacteriaceae family in both human and animal health ${ }^{79,80}$. Among the different types of $b a_{\text {СтХм }}$ reported in Nigeria, bla $a_{\text {СТХм-1, }}$ bla $a_{\text {СтХм-2, }}$ bla $a_{\text {СтХм-14, }}$ and $b l a_{\text {СтХм-55 }}$ are known to be commonly detected in food animals ${ }^{4,8}$. However, the internationally pandemic bla $a_{\text {CTXM-15 }}$ has been reported from every country of the world where it is associated with E. coli serotype O25:H4 (ST131) causing both community and hospital acquired human infections ${ }^{79,81}$. The

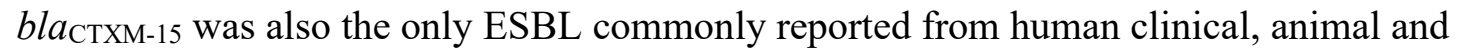
environmental settings in this review. This revealed that bla $a_{\text {СтХм-15 }}$ is ubiquitous and prevalent in all environments with possible anthropozoonotic and zooanthroponotic transmissions. bla $a_{\mathrm{CTXM}-15}$ has also been commonly reported from other regions of Africa ${ }^{71}$, which may suggest bla $_{\text {CTXM-15 }}$ be the predominant ESBL in Africa similar to what's found in USA, Europe, and Asia ${ }^{82}$. bla ESBLs, in particular, bla SHV-12 $_{\text {and }}$ bla $a_{\mathrm{SHV}-2}$ reported in Nigeria, have also been frequently detected in Europe and North America ${ }^{83}$. However, the globally disseminated bla i.e., $b l a_{\mathrm{TEM}-10}$ and $b l a_{\mathrm{TEM}-52}$ were not detected yet in Nigeria, narrow-spectrum $b l a_{\mathrm{TEM}-1}$ coding for ampicillin resistance was however more common.

The proportion estimate of ESBL in Nigeria was 32\% compared to $23 \%$ of AmpC and $8 \%$ of carbapenemases. This is unsurprising, even though AmpC have been found worldwide and carbapenemases are increasingly being reported, both AmpC and carbapenemases are less prevalent than ESBL on the world stage ${ }^{5}$,and this is consistent with the finding of this review. 
The proportion estimate of $29 \%$ for AmpC in a human setting in this review was closed to $28.3 \%$ estimate from Egypt ${ }^{84}$ however, lower than 34\% from Canada ${ }^{85}$ and 39.6\% from Uganda ${ }^{75}$. The proportion estimate of $8 \%$ for carbapenemases is comparable to what has been reported from other African countries ${ }^{77}$. However, the lower proportion of carbapenemases for Nigeria is encouraging considering the importance of carbapenems as last resort antimicrobials in the cases of ESBL producing bacterial infections. While carbapenems resistance is emerging globally at a rapid rate, surveillance, and prudent use practices of carbapenems will help to minimize widespread dissemination and prevention of epidemics of MDR bacterial infections at the national level. The proportion estimate of $32 \%$ of ESBL in human, animal and environmental settings from this review is higher than $22.6 \%$ reported by a similar study from Tanzania ${ }^{73}$.The proportion estimate of $35 \%$ for ESBL in the human clinical setting is comparable to proportions previously reported for different countries within Africa ${ }^{72,71}$. For bla $_{\mathrm{CTXM}}$, the proportion estimate of $34 \%$ for bla Стхм gene in Nigeria was lower compared to $56.7 \%$ reported in Iran ${ }^{86}$ and $69 \%$ from a previous similar systematic review ${ }^{87}$. However, the proportion estimate of $45 \%$ for bla $_{\text {СТХм-15 in Nigeria was lower than } 78 \% \text { reported from both Tanzania }}{ }^{73}$ and Sudan ${ }^{88}$.

None of the articles reviewed reported any risk factors associated with occurrence of beta-lactamase resistance genes in Nigeria, however, the occurrences and proportion estimates of clinically significant beta-lactamases reported maybe due to the uncontrolled and indiscriminate use of antimicrobials as well as the lack of active infection control programs in most animal and human clinical settings. In Nigeria, antimicrobials can readily be purchased from both pharmaceutical and non-pharmaceutical stores in both animal and human clinical settings without prescriptions ${ }^{89}$. This call for concern because indiscriminate use of antimicrobials drives resistance, also, poor hygienic practices in both community and hospital environments facilitates 
the spread and transmission of important MDR bacteria. In addition, extended-spectrum cephalosporins and carbapenems have been designated as critically important antimicrobials by the World Health Organization with limited alternatives in the cases of treatment failure ${ }^{1}$. Lastly, infections with ESBL/AmpC/carbapenemase-producing bacteria may result in prolonged hospitalization, higher treatment costs, delays in the initiation of timely and adequate antimicrobial therapy, increased risk of morbidity and mortality ${ }^{7}$. Therefore, clinically important beta-lactamases represent a significant threat to public health and collaborative efforts at all stakeholders' levels are essential in mitigating the development and dissemination.

While the aim of this review was to provide detailed information on beta-lactamases detected and reported from Nigeria, there are however some limitations of this study. This review was done with the intention of including all available studies that have reported the detection of any beta-lactamase resistance genes in Nigeria. Therefore, there is possibility of selection and information bias introduce due to little emphasis on the quality of the studies reviewed. Also, the literature search for was limited to the PubMed, Google scholar and AJOL electronic databases, therefore, some studies may have been omitted in this review. Also, information on risk factors associated with beta-lactamase resistance was not available. This information is necessary for better explanation for the beta-lactam resistance observed in Nigeria and a better understanding of the epidemiology of beta-lactamase resistance genes in Nigeria. However, this review has provided information on the beta-lactamases distribution in Nigeria. Thirty-six different beta-lactamases have been reported in Nigeria with bla $a_{\text {CTXM-15 commonly }}$ distributed in the animal, human and environment similar to the reports from other African countries. Carbapenemases are most common in human clinical setting however not reported yet in animals. The information provided on beta-lactamase resistance genes is necessary for better 
understanding of one health and molecular epidemiology of clinically important beta-lactamases especially the AmpC, ESBLs, and carbapenemases both locally in Nigeria and globally. 


\section{References}

1. World Health Organization. Critically important antimicrobials for human medicine: ranking of antimicrobial agents for risk management of antimicrobial resistance due to non-human use. vol. 5th rev. Geneva. Licence: CC BY-NC-SA 3.0 IGO (2017).

2. Smet, A. et al. Broad-spectrum $\beta$-lactamases among Enterobacteriaceae of animal origin: molecular aspects, mobility and impact on public health. FEMS Microbiology Reviews 34, 295-316 (2010).

3. Bradford, P. A. Extended-Spectrum -Lactamases in the 21st Century: Characterization, Epidemiology, and Detection of This Important Resistance Threat. Clinical Microbiology Reviews 14, 933-951 (2001).

4. Seiffert, S. N., Hilty, M., Perreten, V. \& Endimiani, A. Extended-spectrum cephalosporin-resistant gram-negative organisms in livestock: An emerging problem for human health? Drug Resistance Updates 16, 22-45 (2013).

5. Pfeifer, Y., Cullik, A. \& Witte, W. Resistance to cephalosporins and carbapenems in Gram-negative bacterial pathogens. International Journal of Medical Microbiology 300, 371-379 (2010).

6. Rousham, E. K., Unicomb, L. \& Islam, M. A. Human, animal and environmental contributors to antibiotic resistance in low-resource settings: integrating behavioural, epidemiological and One Health approaches. Proceedings of the Royal Society B: Biological Sciences 285, 20180332 (2018).

7. Pitout, J. D. \& Laupland, K. B. Extended-spectrum $\beta$-lactamase-producing Enterobacteriaceae: an emerging public-health concern. The Lancet Infectious Diseases 8, 159-166 (2008).

8. EFSA Panel on Biological Hazards (BIOHAZ). Scientific Opinion on the public health risks of bacterial strains producing extended-spectrum $\beta$-lactamases and/or AmpC $\beta$-lactamases in food and food-producing animals: ESBL/AmpC in food-producing animals and foods. EFSA Journal 9, 2322 (2011).

9. Moher, D., Liberati, A., Tetzlaff, J., Altman, D. G. \& PRISMA Group. Preferred reporting items for systematic reviews and meta-analyses: the PRISMA statement. PLoS medicine 6, e1000097e1000097 (2009). 
10. Aibinu, I. E. et al. Extended-Spectrum -Lactamase Enzymes in Clinical Isolates of Enterobacter Species from Lagos, Nigeria. Journal of Clinical Microbiology 41, 2197-2200 (2003).

11. Soge, O. O., Queenan, A. M., Ojo, K. K., Adeniyi, B. A. \& Roberts, M. C. CTX-M-15 extendedspectrum $\beta$-lactamase from Nigerian Klebsiella pneumoniae. Journal of Antimicrobial Chemotherapy 57, 24-30 (2006).

12. Ogunleye, A. O. \& Carlson, S. A. Survey of 3rd generation cephalosporin genes in multi-resistant Salmonella serotypes from septic poultry and an asymptomatic healthy pig from Nigeria. African Journal of Microbiology Research 5, (2011).

13. Ogbolu, D. O., Alli, O. A. T., Olanipekun, L. B., Ojo, O. I. \& Makinde, O. O. Faecal carriage of extended-spectrum beta-lactamase (ESBL)-producing commensal Klebsiella pneumoniae and Escherichia coli from hospital out-patients in Southern Nigeria. International Journal of Medicine and Medicial Sciences 5, 97-105 (2013).

14. Ogbolu, D. O., Daini, O. A., Ogunledun, A., Terry Alli, O. A. \& Webber, M. A. Dissemination of IncF plasmids carrying beta-lactamase genes in Gram-negative bacteria from Nigerian hospitals. The Journal of Infection in Developing Countries 7, (2013).

15. Fortini, D. et al. A novel plasmid carrying blaCTX-M-15 identified in commensal Escherichia coli from healthy pregnant women in Ibadan, Nigeria. Journal of Global Antimicrobial Resistance 3, 9-12 (2015).

16. Titilawo, Y., Obi, L. \& Okoh, A. Antimicrobial resistance determinants of Escherichia coli isolates recovered from some rivers in Osun State, South-Western Nigeria: Implications for public health. Science of The Total Environment 523, 82-94 (2015).

17. Odumosu, B. T., Adeniyi, B. A. \& Chandra, R. First Detection of OXA-10 Extended-Spectrum BetaLactamases and the Occurrence of mexR and $\mathbf{n f x B}$ in Clinical Isolates of Pseudomonas aeruginosa from Nigeria. Chemotherapy 61, 87-92 (2016). 
18. Akinyemi, K. O., Iwalokun, B., Oyefolu, A. \& Fakorede, C. Occurrence of extended-spectrum and AmpC beta-lactamases in multiple drug resistant Salmonella isolates from clinical samples in Lagos, Nigeria. Infection and Drug Resistance Volume 10, 19-25 (2017).

19. Jesumirhewe, C., Springer, B., Lepuschitz, S., Allerberger, F. \& Ruppitsch, W. CarbapenemaseProducing Enterobacteriaceae Isolates from Edo State, Nigeria. Antimicrobial Agents and Chemotherapy 61, (2017).

20. Chah, K. F. et al. Detection and molecular characterisation of extended-spectrum $\beta$-lactamaseproducing enteric bacteria from pigs and chickens in Nsukka, Nigeria. Journal of Global Antimicrobial Resistance 15, 36-40 (2018).

21. Chika, E., Charles, E., Ifeanyichukwu, I. \& Michael, A. First Detection of FOX-1 AmpC $\beta$-lactamase Gene Expression Among Escherichia coli Isolated from Abattoir Samples in Abakaliki, Nigeria. Oman Medical Journal 33, 243-249 (2018).

22. Oyelade, A. A., Adelowo, O. O. \& Fagade, O. E. blaNDM-1-producing Vibrio parahaemolyticus and V. vulnificus isolated from recreational beaches in Lagos, Nigeria. Environmental Science and Pollution Research 25, 33538-33547 (2018).

23. Adenipekun, E. O. et al. Plasmid Replicons and $\beta$-Lactamase-Encoding Genes of Multidrug-Resistant Escherichia coli Isolated from Humans and Food Animals in Lagos, Southwest Nigeria. Microbial Drug Resistance 25, 1410-1423 (2019).

24. Onanuga, A., Mahindroo, J., Singh, S. \& Taneja, N. Phenotypic and molecular characterization of antimicrobial resistant Escherichia coli from urinary tract infections in Port-Harcourt, Nigeria. Pan African Medical Journal 34, (2019).

25. Aibinu, I. et al. Emergence of blaCTX-M-15, qnrB1 and aac(6')-Ib-cr resistance genes in Pantoea agglomerans and Enterobacter cloacae from Nigeria (sub-Saharan Africa). Journal of Medical Microbiology 61, 165-167 (2012). 
26. Kasap, M. et al. Characterization of ESBL (SHV-12) producing clinical isolate of Enterobacter aerogenes from a tertiary care hospital in Nigeria. Annals of Clinical Microbiology and Antimicrobials 9, 1 (2010).

27. Olowe, O. A. et al. Detection of blaCTX-M-15 extended-spectrum $\beta$-lactamase genes in Escherichia coli from hospital patients in Nigeria. International Journal of Antimicrobial Agents 35, 206-207 (2010).

28. Olowe, O. A., Oladipo, G. O., Makanjuola, O. A. \& Olaitan, J. O. Antimicrobial susceptibility and occurrence of resistance genes among Salmonella arizonae isolated from chicken meat samples in Sokoto metropoplis Sokoto State, Nigeria. International Journal of Pharma Medicine \& Biological Sciences 1, 129-138 (2012).

29. Olowe, O. A., Adewumi, O., Odewale, G., Ojurongbe, O. \& Adefioye, O. J. Phenotypic and Molecular Characterisation of Extended-Spectrum Beta-Lactamase Producing Escherichia coli Obtained from Animal Fecal Samples in Ado Ekiti, Nigeria. Journal of Environmental and Public Health 2015, 1-7 (2015).

30. Fortini, D., Fashae, K., Garcia-Fernandez, A., Villa, L. \& Carattoli, A. Plasmid-mediated quinolone resistance and -lactamases in Escherichia coli from healthy animals from Nigeria. Journal of Antimicrobial Chemotherapy 66, 1269-1272 (2011).

31. Isaiah, I., Nche, B., Nwagu, I. \& Nwagu, I. Incidence of temonera, sulphuhydryl variables and cefotaximase genes associated with beta-lactamase producing escherichia coli in clinical isolates. North American Journal of Medical Sciences 554-558 (2011) doi:10.4297/najms.2011.3554.

32. Iroha, I. R. et al. First description of Escherichia coli producing CTX-M-15- extended spectrum beta lactamase (ESBL) in out-patients from south eastern Nigeria. Annals of Clinical Microbiology and Antimicrobials 11, 19 (2012).

33. Akujobi, C. N. \& Ezeanya, C. C. Emergence of carbapenem resistance among extended-spectrum beta-lactamase isolate of Escherichia coli from clinical specimens in a tertiary hospital, Nigeria. International Journal of Microbiology Research 5, 367-370 (2013). 
34. Ogbolu, D. O., Terry Alli, O. A., Webber, M. A., Oluremi, A. S. \& Oloyede, O. M. CTX-M-15 is established in most multidrug-resistant uropathogenic Enterobacteriaceae and Pseudomonaceae from hospitals in Nigeria. European Journal of Microbiology and Immunology 8, 20-24 (2018).

35. Inwezerua, C. et al. Occurrence of extended-spectrum beta-lactamases in human and bovine isolates of Escherichia coli from Oyo state, Nigeria. The Journal of Infection in Developing Countries 8, (2014).

36. Akinyemi, K. O., Iwalokun, B., Alafe, O., Mudashiru, S. \& Fakorede, C. blaCTX-M-I group extended spectrum beta lactamase-producing Salmonella typhi from hospitalized patients in Lagos, Nigeria. Infection and Drug Resistance 99 (2015) doi:10.2147/IDR.S78876.

37. Raji, M. A., Jamal, W., Ojemeh, O. \& Rotimi, V. O. Sequence analysis of genes mediating extendedspectrum beta-lactamase (ESBL) production in isolates of Enterobacteriaceae in a Lagos Teaching Hospital, Nigeria. BMC Infectious Diseases 15, (2015).

38. Adesoji, A. T. \& Ogunjobi, A. A. Detection of Extended Spectrum Beta-Lactamases Resistance Genes among Bacteria Isolated from Selected Drinking Water Distribution Channels in Southwestern Nigeria. BioMed Research International 2016, 1-9 (2016).

39. Aernan, P. T. \& Umeh, E. U. Molecular Characterization of Extended-Spectrum Beta-Lactamase (ESBLs) genes in Pseudomonas aeruginosa from Pregnant Women Attending a Tertiary Health Care Centre in Makurdi, Central Nigeria. International Journal of Scientific and Research Publications 6, $19-25$ (2016).

40. Afiukwa, A. et al. First Report of blaCTX-M-15 Extended Spectrum Beta-Lactamase (Esbl) Producing E. Coli Isolated from Cloacal Swabs of Birds in South Eastern Nigeria. International Archives of BioMedical and Clinical Research 2, (2016).

41. Mohammed, Y. Characterization of Extended- Spectrum Beta-lactamase from Escherichia coli and Klebsiella Species from North Eastern Nigeria. JOURNAL OF CLINICAL AND DIAGNOSTIC RESEARCH (2016) doi:10.7860/JCDR/2016/16330.7254. 
42. Odewale, G., Adefioye, O. J., Ojo, J., Adewumi, F. A. \& Olowe, O. A. Multidrug resistance of Acinetobacter baumannii in Ladoke Akintola University Teaching Hospital, Osogbo, Nigeria. European Journal of Microbiology and Immunology 6, 238-243 (2016).

43. Ojo, O. E., Schwarz, S. \& Michael, G. B. Detection and characterization of extended-spectrum $\beta$ lactamase-producing Escherichia coli from chicken production chains in Nigeria. Veterinary Microbiology 194, 62-68 (2016).

44. Onyenwe, N. E. Molecular characterization of some multi-drug resistant Salmonella enterica of human origin in Southeast, Nigeria. MSc Thesis, University of Ibadan, Nigeria 1-174 (2016).

45. Alabi, O. S., Mendonça, N., Adeleke, O. E. \& Da Silva, G. J. Molecular screening of antibioticresistant determinants among multidrug-resistant clinical isolates of Proteus mirabilis from SouthWest Nigeria. African Health Sciences 17, 356 (2017).

46. Obasi, A. et al. Extended-Spectrum $\beta$-Lactamase-Producing Klebsiella pneumoniae from Pharmaceutical Wastewaters in South-Western Nigeria. Microbial Drug Resistance 23, 1013-1018 (2017).

47. Olatunji, M. K., Olayemi, A. \& Jimoh, F. Distribution Profile of Extended Spectrum Beta Lactamase (ESBL) producing Escherichia coli Isolates from Asa River (Nigeria). Journal of Applied Sciences and Environmental Management 20, 973 (2017).

48. Thonda, O. \& Oluduro, A. Molecular Characterization of ESBLs Genes among Multi-drug Resistant Klebsiella species in Ile-Ife South-West, Nigeria. Journal of Advances in Microbiology 7, 1-9 (2017).

49. Adelowo, O. O. et al. Extended Spectrum Beta-Lactamase (ESBL)-producing bacteria isolated from hospital wastewaters, rivers and aquaculture sources in Nigeria. Environmental Science and Pollution Research 25, 2744-2755 (2018).

50. Adeluola, A. O., Oyedeji, K. S., Mendie, U. E., Johnson, J. R. \& Porter, J. R. Detection, inhibition and molecular analysis of multidrug resistant aerobic gram-negative clinical isolates from a tertiary hospital in Nigeria. African Journal of Biomedical Research 21, 15-21-21 (2018). 
51. Akinbami, O. R., Olofinsae, S. \& Ayeni, F. A. Prevalence of extended spectrum beta lactamase and plasmid mediated quinolone resistant genes in strains of Klebsiella pneumonia, Morganella morganii, Leclercia adecarboxylata and Citrobacter freundii isolated from poultry in South Western Nigeria. PeerJ 6, e5053 (2018).

52. Okpara, E. O. et al. Antimicrobial usage and presence of extended-spectrum $\beta$-lactamase-producing Enterobacteriaceae in animal-rearing households of selected rural and peri-urban communities. Veterinary Microbiology 218, 31-39 (2018).

53. Olowo-okere, A., Ibrahim, Y. K. E. \& Olayinka, B. O. Molecular characterisation of extendedspectrum $\beta$-lactamase-producing Gram-negative bacterial isolates from surgical wounds of patients at a hospital in North Central Nigeria. Journal of Global Antimicrobial Resistance 14, 85-89 (2018).

54. Adesina, T., Nwinyi, O., De, N., Akinnola, O. \& Omonigbehin, E. First Detection of CarbapenemResistant Escherichia fergusonii Strains Harbouring Beta-Lactamase Genes from Clinical Samples. Pathogens 8, 164 (2019).

55. Nwafia, I. N., Ohanu, M. E., Ebede, S. O. \& Ozumba, U. C. Molecular detection and antibiotic resistance pattern of extended-spectrum beta-lactamase producing Escherichia coli in a Tertiary Hospital in Enugu, Nigeria. Annals of Clinical Microbiology and Antimicrobials 18, (2019).

56. Tsaku, P. A. et al. Extended-Spectrum Beta-Lactamase-production in Escherichia coli isolated from door handles in Nasarawa State University, Keffi, Nigeria. Heliyon 5, e02177 (2019).

57. Igwe, J. C. et al. Molecular Characterization of Extended Spectrum \&lt;i\&gt; $\beta \& 1 t ; / i \& g t ;-L a c t a m a s e$ Genes in Clinical \&lt;i\&gt;E. coli\&lt;/i\&gt; Isolates. Journal of Biomedical Science and Engineering 07, 276-285 (2014).

58. Ugwu, I. C. Characterization of avian pathogenic Escherichia coli and extended-spectrum betalactamase producing Escherichia coli isolated from chickens in Enugu State, Nigeria. PhD Thesis, University of Nigeria Nsukka Nigeria 1-216 (2015).

59. Brinkac, L. M. et al. Emergence of New Delhi Metallo- $\square$-Lactamase (NDM-5) in Klebsiella quasipneumoniae from Neonates in a Nigerian Hospital. 4, 10 (2019). 
60. Olaitan, A. O. et al. Emergence of multidrug-resistant Acinetobacter baumannii producing OXA-23 carbapenemase, Nigeria. International Journal of Infectious Diseases 17, e469-e470 (2013).

61. Ogbolu, D. O. \& Webber, M. A. High-level and novel mechanisms of carbapenem resistance in Gram-negative bacteria from tertiary hospitals in Nigeria. International Journal of Antimicrobial Agents 43, 412-417 (2014).

62. Mohammed, Y., Zailani, S. B. \& Onipede, A. O. Characterization of KPC, NDM and VIM Type Carbapenem Resistance \&lt;i\&gt;Enterobacteriaceae\&lt;/i\&gt; from North Eastern, Nigeria. Journal of Biosciences and Medicines 03, 100-107 (2015).

63. Walkty, A. et al. Isolation of multiple carbapenemase-producing Gram-negative bacilli from a patient recently hospitalized in Nigeria. Diagnostic Microbiology and Infectious Disease 81, 296-298 (2015).

64. Uwaezuoke, N. S., Kieffer, N., Iregbu, K. C. \& Nordmann, P. First report of OXA-181 and NDM-1 from a clinical Klebsiella pneumoniae isolate from Nigeria. International Journal of Infectious Diseases 61, 1-2 (2017).

65. Adelowo, O. O., Vollmers, J., Mäusezahl, I., Kaster, A.-K. \& Müller, J. A. Detection of the carbapenemase gene blaVIM-5 in members of the Pseudomonas putida group isolated from polluted Nigerian wetlands. Scientific Reports 8, (2018).

66. Zubair, K. \& Iregbu, K. in Clinical Isolates of Pseudomonas aeruginosa in a Central Nigeria. Nigeria Journal of Clinical practice 21, 176-182 (2018).

67. Iredell, J., Brown, J. \& Tagg, K. Antibiotic resistance in Enterobacteriaceae: mechanisms and clinical implications. BMJ h6420 (2016) doi:10.1136/bmj.h6420.

68. Ekwanzala, M. D., Dewar, J. B., Kamika, I. \& Momba, M. N. B. Systematic review in South Africa reveals antibiotic resistance genes shared between clinical and environmental settings. Infection and Drug Resistance Volume 11, 1907-1920 (2018).

69. Liebana, E. et al. Public Health Risks of Enterobacterial Isolates Producing Extended-Spectrum Lactamases or AmpC -Lactamases in Food and Food-Producing Animals: An EU Perspective of 
Epidemiology, Analytical Methods, Risk Factors, and Control Options. Clinical Infectious Diseases 56, 1030-1037 (2013).

70. Köck, R. et al. Carbapenem-resistant Enterobacteriaceae in wildlife, food-producing, and companion animals: a systematic review. Clinical Microbiology and Infection 24, 1241-1250 (2018).

71. Storberg, V. ESBL-producing Enterobacteriaceae in Africa - a non-systematic literature review of research published 2008-2012. Infection Ecology \& Epidemiology 4, 20342 (2014).

72. Sonda, T. et al. Meta-analysis of proportion estimates of Extended-Spectrum-Beta-Lactamaseproducing Enterobacteriaceae in East Africa hospitals. Antimicrobial Resistance \& Infection Control 5, (2016).

73. Seni, J. et al. Preliminary insights into the occurrence of similar clones of extended-spectrum betalactamase-producing bacteria in humans, animals and the environment in Tanzania: A systematic review and meta-analysis between 2005 and 2016. Zoonoses and Public Health 65, 1-10 (2018).

74. Collignon, P. \& McEwen, S. One Health—Its Importance in Helping to Better Control Antimicrobial Resistance. Tropical Medicine and Infectious Disease 4, 22 (2019).

75. Nakaye, M. et al. AmpC-BETA Lactamases among Enterobacteriaceae Isolated at a Tertiary Hospital, South Western Uganda. British Biotechnology Journal 4, 1026-1036 (2014).

76. Guerra, B., Fischer, J. \& Helmuth, R. An emerging public health problem: Acquired carbapenemaseproducing microorganisms are present in food-producing animals, their environment, companion animals and wild birds. Veterinary Microbiology 171, 290-297 (2014).

77. Manenzhe, R. I., Zar, H. J., Nicol, M. P. \& Kaba, M. The spread of carbapenemase-producing bacteria in Africa: a systematic review. Journal of Antimicrobial Chemotherapy 70, 23-40 (2015).

78. Sekyere, J. O., Govinden, U. \& Essack, S. The Molecular Epidemiology and Genetic Environment of Carbapenemases Detected in Africa. Microbial Drug Resistance 22, 59-68 (2016).

79. Cantón, R., González-Alba, J. M. \& Galán, J. C. CTX-M Enzymes: Origin and Diffusion. Frontiers in Microbiology 3, (2012). 
80. Cantón, R. \& Coque, T. M. The CTX-M $\beta$-lactamase pandemic. Current Opinion in Microbiology 9, $466-475$ (2006).

81. Peirano, G. \& Pitout, J. D. D. Molecular epidemiology of Escherichia coli producing CTX-M $\beta$ lactamases: the worldwide emergence of clone ST131 O25:H4. International Journal of Antimicrobial Agents 35, 316-321 (2010).

82. Bevan, E. R., Jones, A. M. \& Hawkey, P. M. Global epidemiology of CTX-M $\beta$-lactamases: temporal and geographical shifts in genotype. Journal of Antimicrobial Chemotherapy 72, 2145-2155 (2017).

83. Liakopoulos, A., Mevius, D. \& Ceccarelli, D. A Review of SHV Extended-Spectrum $\beta$-Lactamases: Neglected Yet Ubiquitous. Frontiers in Microbiology 7, (2016).

84. Fam, N. et al. Prevalence of Plasmid-Mediated ampC Genes in Clinical Isolates of Enterobacteriaceae from Cairo, Egypt. British Microbiology Research Journal 3, 525-537 (2013).

85. Pitout, J. D. D., Gregson, D. B., Church, D. \& Laupland, K. B. Population-based Laboratory Surveillance for AmpC $\beta$-Lactamase-producing Escherichia coli, Calgary. Emerging Infectious Diseases 13, 443-448 (2007).

86. Eskandari-Nasab, E., Moghadampour, M. \& Tahmasebi, A. Prevalence of blaCTX-M Gene among Extended- Spectrum $\beta$-Lactamases Producing Klebsiella pneumoniae Clinical Isolates in Iran: A Meta-Analysis. 43, 8 (2018).

87. Karanika, S., Karantanos, T., Arvanitis, M., Grigoras, C. \& Mylonakis, E. Fecal Colonization With Extended-spectrum Beta-lactamase-Producing Enterobacteriaceae and Risk Factors Among Healthy Individuals: A Systematic Review and Metaanalysis. Clinical Infectious Diseases 63, 310-318 (2016).

88. Altayb, H. N., Siddig, M. A. M., Amin, N. M. E., Hashim, A. I. \& Mukhtar, M. Molecular Characterization of CTX-M ESBLs among Pathogenic Enterobacteriaceae isolated from different regions in Sudan. Global Advanced Research Journal of Microbiology 7, 40-46 (2018). 
89. Adesokan, H. K., Akanbi, I. O., Akanbi, I. M. \& Obaweda, R. A. Pattern of antimicrobial usage in livestock animals in south-western Nigeria: The need for alternative plans. Onderstepoort Journal of Veterinary Research; Vol 82, No 1 (2015)DO - 10.4102/ojvr.v82i1.816 (2015). 
Figure 1. Flow diagram summarizing the process of literature search and selection.

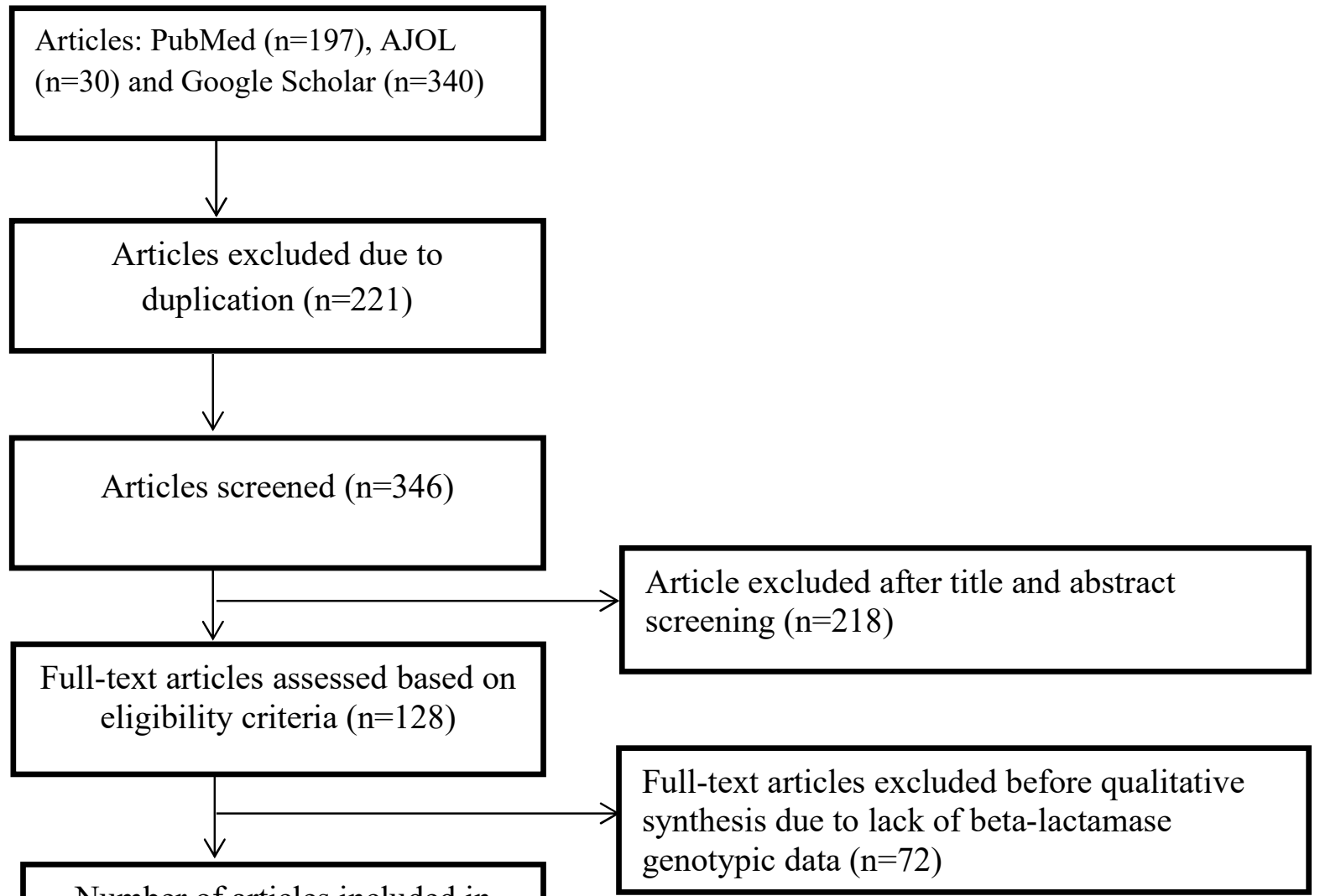

Number of articles included in qualitative analysis $(n=63)$ 
1 Table 1. Distribution of beta-lactamase resistance genes between animals, humans and environmental settings in Nigeria

\begin{tabular}{|c|c|c|c|c|c|}
\hline Beta-lactamase types & Genes & Animals & Humans & Environment & Reference \\
\hline \multirow[t]{8}{*}{ AmpC beta-lactamases } & bla $a_{\mathrm{ampC}}$ & $1^{\mathrm{a}}$ & 5 & 1 & \multirow[t]{8}{*}{$10-24$} \\
\hline & bla $_{\mathrm{CMY}-2}$ & 1 & & & \\
\hline & bla $a_{\mathrm{CMY}}$ like & 1 & 1 & 1 & \\
\hline & $b l a_{\mathrm{ACT}-5}$ & 1 & & & \\
\hline & $b l a_{\mathrm{ACC}}$ & 1 & & & \\
\hline & bla $a_{\mathrm{FOX}-1}$ & 2 & & & \\
\hline & bla $a_{\text {DHA-1 }}$ & 1 & 1 & & \\
\hline & bla $a_{\mathrm{ECB}}$ & 1 & & & \\
\hline \multirow{14}{*}{ Extended-spectrum beta-lactamases } & bla $_{\text {СтХ-м like }}$ & 3 & 12 & 1 & \multirow[t]{14}{*}{$10-15,17,19,20,23-56$} \\
\hline & bla $a_{\mathrm{CTX}-\mathrm{M}-1}$ & 2 & 2 & & \\
\hline & bla ${ }_{\mathrm{CTX}-\mathrm{M}-2}$ & & 1 & & \\
\hline & bla $a_{\mathrm{CTX}-\mathrm{M}-14}$ & 1 & 1 & & \\
\hline & bla $a_{\mathrm{CTX}-\mathrm{M}-15}$ & 6 & 14 & 2 & \\
\hline & $b l a_{\mathrm{CTX}-\mathrm{M}-27}$ & 1 & & & \\
\hline & bla $a_{\text {CTX-M-55 }}$ & 1 & & & \\
\hline & $b_{l a} a_{\mathrm{SHV}-2}$ & & 1 & 1 & \\
\hline & bla $a_{\mathrm{SHV}-12}$ & & 2 & 1 & \\
\hline & bla $a_{\mathrm{SHV}-28}$ & & 1 & & \\
\hline & bla $a_{\mathrm{SHV}-112}$ & & 1 & & \\
\hline & bla $\mathrm{OXA}-10$ & & 1 & & \\
\hline & $b l a_{\mathrm{VEB}-1}$ & 1 & 1 & & \\
\hline & $b l a_{\mathrm{GES}}$ & 1 & 1 & & \\
\hline \multirow[t]{7}{*}{ Narrow-spectrum beta-lactamases } & bla $a_{\text {OXA-1 }}$ & 2 & 4 & & \multirow[t]{7}{*}{$13-16,19,24,32,35,37,43,57-59$} \\
\hline & bla $a_{\text {OXA-2 }}$ & 1 & 1 & & \\
\hline & $b_{\text {bHV-1 }}$ & & 2 & 1 & \\
\hline & bla $a_{\mathrm{SHV}-11}$ & & 2 & 1 & \\
\hline & bla $a_{\mathrm{TEM}-1}$ & 3 & 6 & 1 & \\
\hline & bla $a_{\mathrm{TEM}-2}$ & & 1 & & \\
\hline & bla & & & 1 & \\
\hline
\end{tabular}

(1)

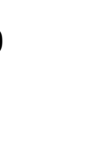

(2)

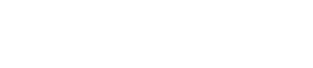

(n) 


\begin{tabular}{|c|c|c|c|c|}
\hline \multirow[t]{9}{*}{ Carbapenemases } & $b l a_{\mathrm{KPC}}$ & 1 & & \multirow[t]{9}{*}{$19,22,59-66$} \\
\hline & bla $a_{\mathrm{OXA}-23}$ & 1 & & \\
\hline & bla $a_{\text {OXA-48 }}$ & 1 & & \\
\hline & $b^{\prime} a_{\text {OXA-181 }}$ & 3 & & \\
\hline & $b l a_{\mathrm{NDM}-1}$ & 5 & 1 & \\
\hline & $b l a_{\mathrm{NDM}-5}$ & 1 & & \\
\hline & bla ${ }_{\mathrm{VIM}-1}$ & 5 & & \\
\hline & bla $a_{\mathrm{VIM}-2}$ & 1 & & \\
\hline & bla ${ }_{\mathrm{VIM}-5}$ & & 1 & \\
\hline
\end{tabular}

${ }^{a}$ Value in each cell represents the number of articles reporting the beta-lactamase genes

3

4

5

6 


\begin{tabular}{|c|c|c|c|c|}
\hline Study & ESBL & & ES $(95 \%$ CI) & Reference \\
\hline Animal & & i & & \\
\hline Ojo et al 2016 & СТХм- 15 & i & $0.01(0.00,0.03)$ & 43 \\
\hline Fortini et al 2011 & СТХм- 15 & i & $0.01(0.00,0.06)$ & 30 \\
\hline Adenipekun et al 2019 & стХм & i & $0.01(0.00,0.04)$ & 23 \\
\hline Okpara et al 2018 & СТХм- 55 & I & $0.02(0.00,0.10)$ & 52 \\
\hline Okpara et al 2018 & СТХМ-27 & I & $0.02(0.00,0.10)$ & 52 \\
\hline Okpara et al 2018 & СТХМ- 14 & I & $0.04(0.01,0.13)$ & 52 \\
\hline Chah et al 2018 & VEB & I & $0.05(0.01,0.25)$ & 20 \\
\hline Chah et al 2018 & СтХм-1 & $\perp$ & $0.16(0.06,0.38)$ & 20 \\
\hline Akinbami et al 2018 & Стхм & 1 & $0.35(0.22,0.50)$ & 51 \\
\hline Olowe et al 2015 & стхм & 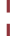 & $0.57(0.46,0.66)$ & 29 \\
\hline Afiukwa et al 2016 & СтХм- 15 & i & $0.75(0.47,0.91)$ & 40 \\
\hline Chah et al 2018 & СТХМ- 15 & i & $0.79(0.57,0.91)$ & 20 \\
\hline Okpara et al 2018 & СТХМ- 15 & i & $0.92(0.82,0.97)$ & 52 \\
\hline \multicolumn{2}{|c|}{ Subtotal $\left(\mathrm{I}^{\wedge} 2=98.60 \%, \mathrm{p}=0.00\right)$} & 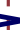 & $0.25(0.17,0.33)$ & \\
\hline & & i & & \\
\hline Human & & I & & \\
\hline Jesumirhewe et al 2017 & SHV11/28 & I & $0.02(0.01,0.05)$ & 19 \\
\hline Jesumirhewe et al 2017 & СТХМ- 15 & I & $0.02(0.01,0.05)$ & 19 \\
\hline Raji et al 2015 & SHV-12 & I & $0.05(0.01,0.17)$ & 37 \\
\hline Raji et al 2015 & SHV-112 & I & $0.05(0.01,0.17)$ & 37 \\
\hline Alabi et al 2017 & СТХМ- 15 & I & $0.07(0.03,0.16)$ & 45 \\
\hline Aibinu et al 2012 & СТХМ- 15 & 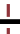 & $0.10(0.02,0.40)$ & 25 \\
\hline Aernan and Umeh 2016 & СТХм & I & $0.11(0.04,0.27)$ & 39 \\
\hline Isaiah et al 2011 & СтХм & 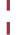 & $0.13(0.09,0.18)$ & 31 \\
\hline Inwezerua et al 2014 & СтХм- 15 & i & $0.14(0.07,0.25)$ & 35 \\
\hline Adeluola et al 2018 & стХм & & $0.20(0.08,0.42)$ & 50 \\
\hline Aibinu et al 2003 & SHV-2 & & $0.20(0.10,0.35)$ & 10 \\
\hline Olowe et al 2012 & стХм & & $0.22(0.12,0.38)$ & 28 \\
\hline Ogbolu and Webber 2014 & GES & & $0.25(0.14,0.40)$ & 61 \\
\hline Ogbolu et al $2013 \mathrm{~b}$ & СТХМ- 15 & 4 & $0.26(0.19,0.35)$ & 14 \\
\hline Mohammed et al 2016 & стхм & $\perp$ & $0.27(0.20,0.36)$ & 41 \\
\hline Adenipekun et al 2019 & стхм & & $0.28(0.22,0.34)$ & 23 \\
\hline Ogbolu et al 2018 & VEB-1 & 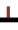 & $0.29(0.14,0.50)$ & 34 \\
\hline Thonda and Oluduro 2017 & стхм & $\perp$ & $0.35(0.26,0.44)$ & 48 \\
\hline Onyenwe 2016 & стхм & 1 & $0.36(0.22,0.52)$ & 44 \\
\hline Ogbolu et al 2018 & СТХМ- 14 & $\frac{1}{1}$ & $0.38(0.21,0.59)$ & 50 \\
\hline Odewale et al 2016 & стХм & $\frac{1}{1}$ & $0.45(0.21,0.72)$ & 42 \\
\hline Akinyemi et al 2015 & СтХм-1 & 1 & $0.46(0.28,0.65)$ & 36 \\
\hline Olowo-okere et al 2018 & стхм & $T$ & $0.54(0.29,0.77)$ & 53 \\
\hline Soge et al 2016 & СТХМ- 15 & i & $0.57(0.39,0.73)$ & 11 \\
\hline Onanuga et al 2019 & СТХМ- 15 & i & $0.64(0.45,0.80)$ & 24 \\
\hline Ogbolu et al $2013 \mathrm{~b}$ & СТХм-2 & i & $0.67(0.44,0.84)$ & 14 \\
\hline Olowe et al 2010 & СТХМ- 15 & i & $0.75(0.47,0.91)$ & 27 \\
\hline Raji et al 2015 & СТХМ- 15 & i & $0.79(0.64,0.89)$ & 37 \\
\hline Odumosu et al 2015 & OXA-10 & I & $0.80(0.58,0.92)$ & 17 \\
\hline Ogbolu et al 2013a & СТХM- 15 & 1 & $0.89(0.73,0.96)$ & 13 \\
\hline Ogbolu et al 2018 & СТХМ- 15 & I & $0.95(0.77,0.99)$ & 50 \\
\hline \multicolumn{2}{|c|}{ Subtotal $\left(\mathrm{I}^{\wedge} 2=97.33 \%, \mathrm{p}=0.00\right)$} & & $0.35(0.27,0.43)$ & \\
\hline Environment & & i & & \\
\hline Adesoji and Ogunjobi 2016 & стХм & 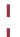 & $0.05(0.02,0.13)$ & 38 \\
\hline Olatunji et al 2017 & стхм & I & $0.19(0.11,0.31)$ & 47 \\
\hline Adelowo et al 2018b & СТХМ- 15 & i & $0.41(0.33,0.50)$ & 49 \\
\hline \multirow[t]{2}{*}{ Subtotal $\left(\mathrm{I}^{\wedge} 2=\%, \mathrm{p}=.\right)$} & & & $0.22(-0.01,0.44)$ & \\
\hline & & T & & \\
\hline \multicolumn{2}{|c|}{ Heterogeneity between groups: $p=0.157$} & 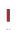 & & \\
\hline Overall $\left(\mathrm{I}^{\wedge} 2=97.87 \%, \mathrm{p}=\right.$ & & & $0.31(0.26,0.36)$ & \\
\hline
\end{tabular}

16 Figure 2: Subgroup analysis and forest plot of proportion estimates of extended-spectrum beta17 lactamases (ESBL) for human, animal, and environmental settings in Nigeria. Midpoint of each 18 horizontal line segment shows the proportion estimate of ESBL resistance genes in each study. 19 Diamond sign represents the pooled proportion from all studies included in the random-effect meta-analysis. CI: Confidence interval. 


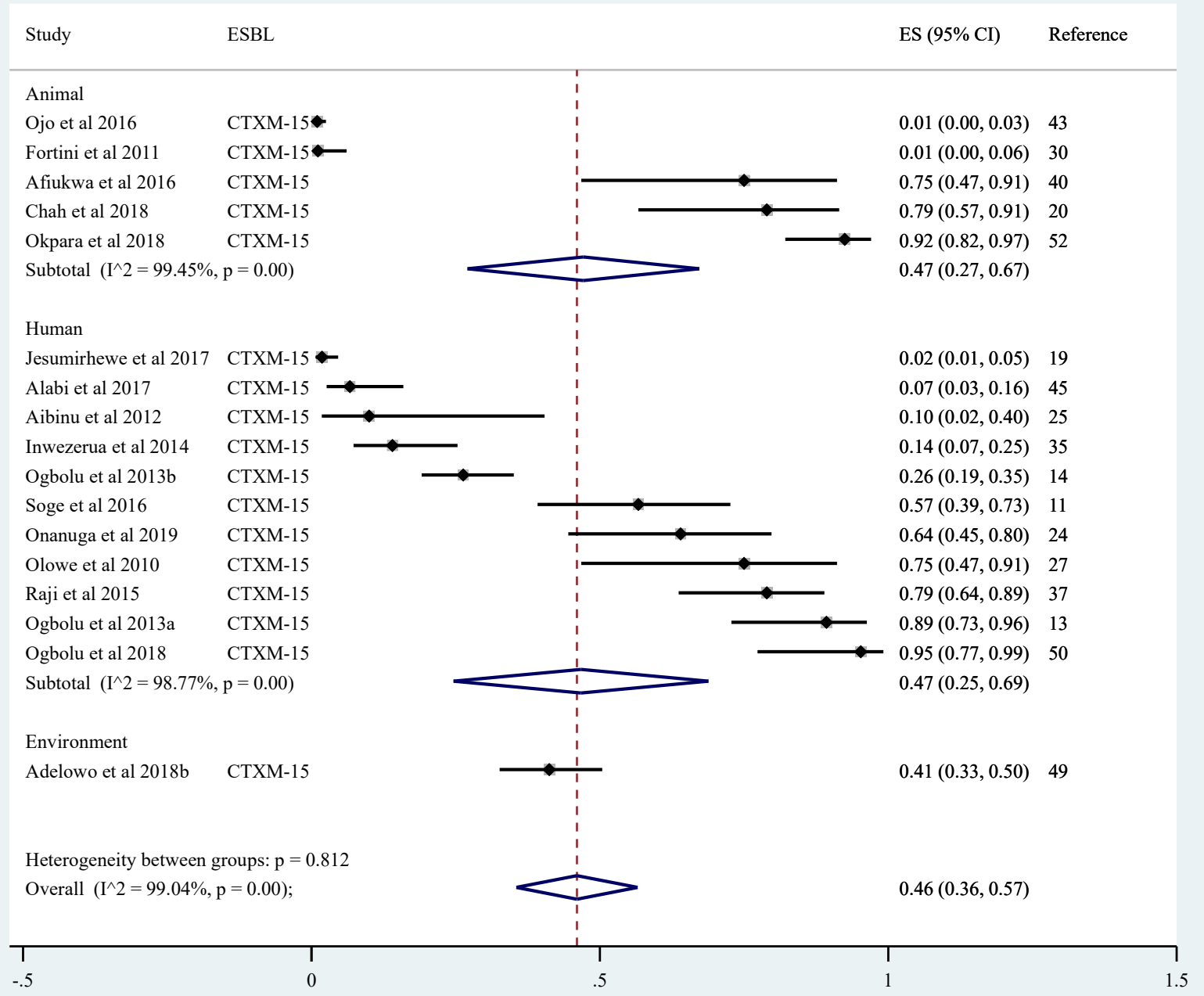

22 Figure 3: Subgroup analysis and forest plot of proportion estimates of bla $a_{\mathrm{CTXM}-15}$ extended23 spectrum beta-lactamase (ESBL) in Nigeria. Midpoint of each horizontal line segment shows the 24 proportion estimate of bla $a_{\mathrm{CTXM}-15}$ resistance gene in each study. Diamond sign represents the 25 pooled proportion from all studies included in the random-effect meta-analysis. CI: Confidence interval. 


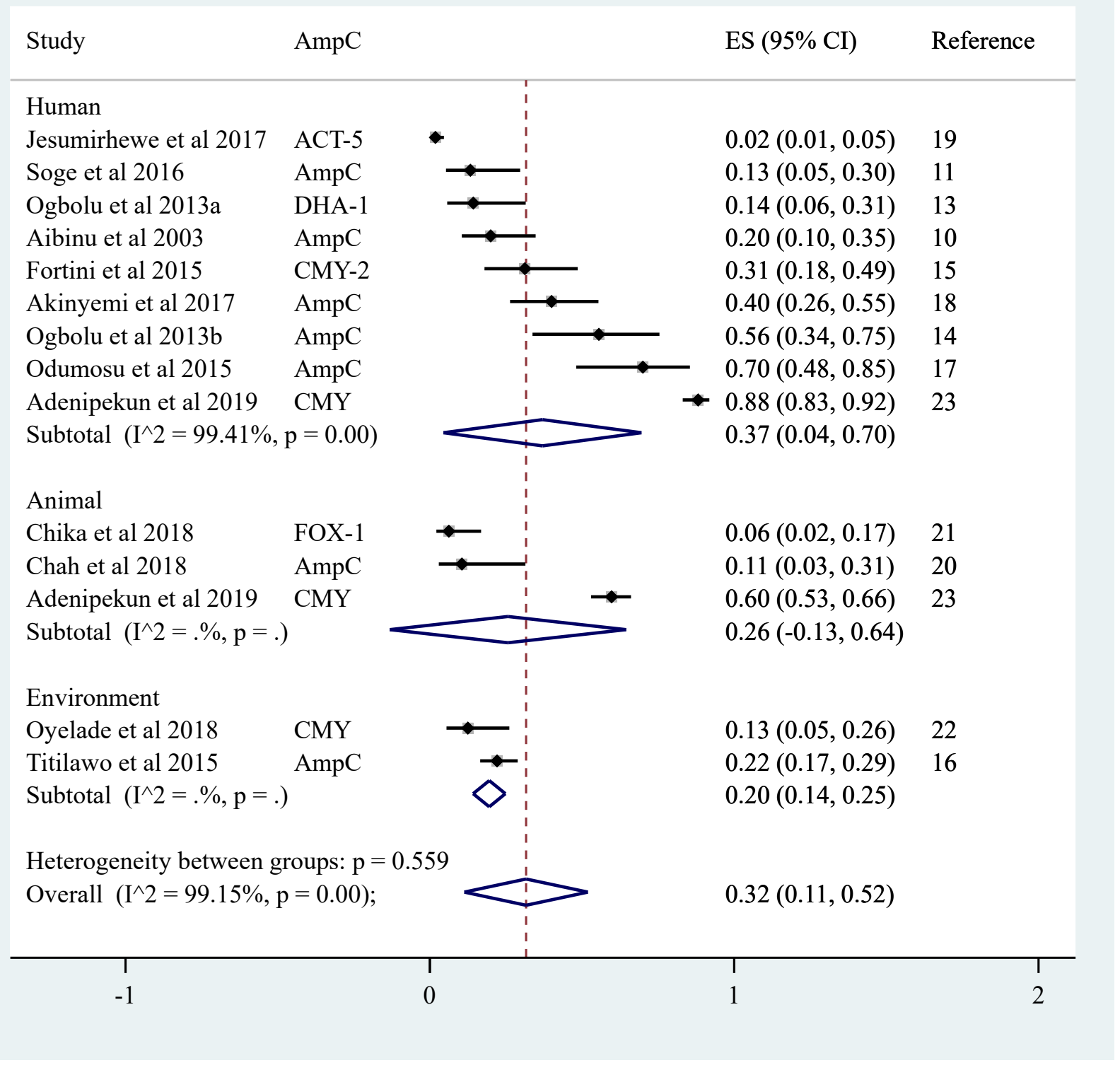

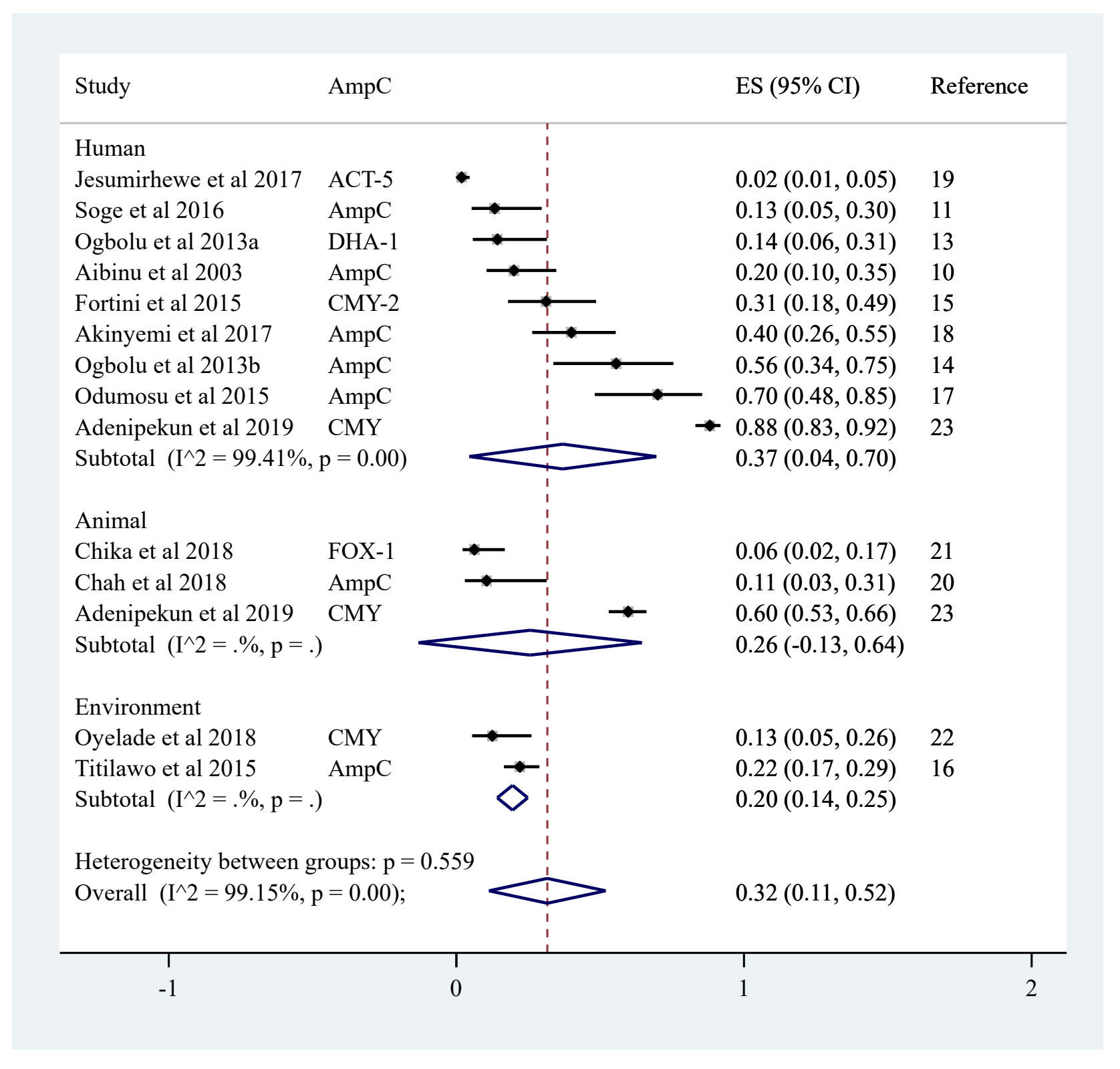

Figure 4: Subgroup analysis and forest plot of proportion estimates of AmpC beta-lactamases for human, animal, and environmental settings in Nigeria. Midpoint of each horizontal line segment shows the proportion estimate of AmpC resistance genes in each study. Diamond sign represents the pooled proportion from all studies included in the random-effect meta-analysis.

CI: Confidence interval. 


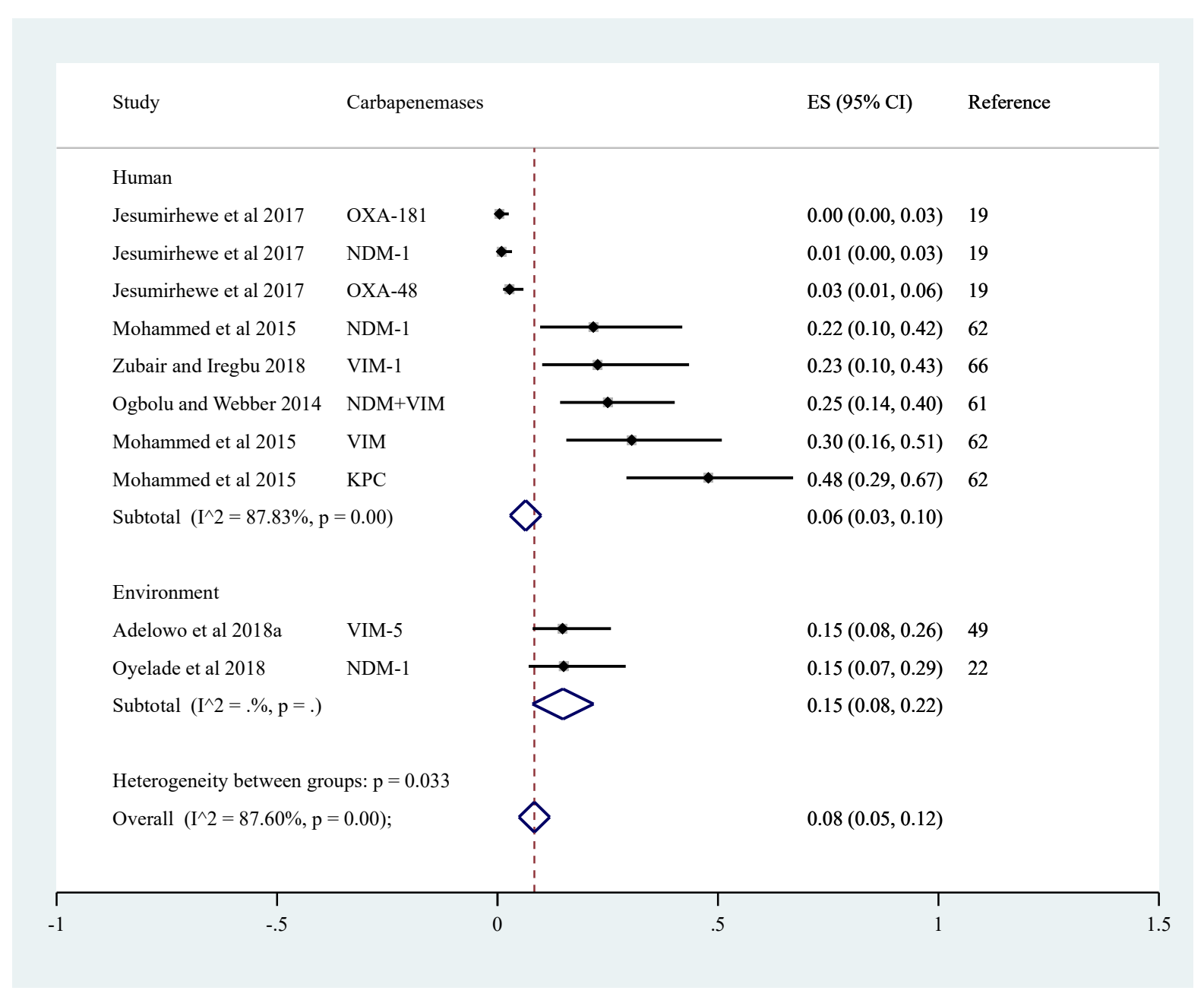

Figure 5: Subgroup analysis and forest plot of proportion estimates of carbapenemase betalactamases for human and environmental settings in Nigeria. Midpoint of each horizontal line segment shows the proportion estimate of carbapenemase resistance genes in each study. Diamond sign represents the pooled proportion from all studies included in the random-effect meta-analysis. CI: Confidence interval. 